Vol. 9, No. 1.

ISSN: 1473-8376

www.heacademy.ac.uk/johlste

ACADEMIC PAPER

\title{
Facilitating and integrating learning within sport studies cooperative education: Exploring the pedagogies employed by students, academics and workplace supervisors
}

\author{
Andrew Martin (a.j.martin@massey.ac.nz) \\ School of Management, Massey University, Palmerston North, New Zealand \\ Jenny Fleming (jenny.fleming@aut.ac.nz) \\ AUT University, Auckland, New Zealand \\ Lesley Ferkins (lesley.ferkins@deakin.edu.au) \\ School of Management and Marketing, Deakin University, Victoria, Australia \\ Cindy Wiersma (cindy.wiersma@aut.ac.nz) \\ AUT University, Auckland, New Zealand \\ Richard Coll (r.coll@waikato.ac.nz) \\ University of Waikato, Hamilton, New Zealand
}

DOI:10.3794/johlste.91.239

○ Journal of Hospitality, Leisure, Sport and Tourism Education

\begin{abstract}
Using an interpretative case study methodology, the pedagogical approaches used to facilitate and integrate student learning in cooperative education programmes in sport studies were investigated. This research drew from two New Zealand university cohorts and involved six focus group interviews. Findings suggested there were limited direct explicit attempts to integrate on- and off-campus learning. Integration was implicitly or indirectly fostered, principally by reflection through assessments (e.g., journals, reports), and primarily consisted of reflection-on-action (Schön, 1991) after the learning activities. Significantly, the integration

Andrew J Martin PhD, is an Associate Professor in Sport Management and Coaching, School of Management, at Massey University, Palmerston North, New Zealand

Jenny M Fleming MSc (Hons), Grad Dip T. Ed, is a Senior Lecturer and coordinator for Cooperative Education in the Bachelor of Sport \& Recreation and Bachelor of Dance degrees at AUT University, Auckland, New Zealand. She is currently the Deputy Chairperson of the New Zealand Association for Cooperative Education.
\end{abstract}

Lesley Ferkins PhD, is a Senior Lecturer in the School of Management and Marketing, Deakin University, Victoria, Australia.

Cindy Wiersma MPE, is a Senior Lecturer and Programme Leader in the Bachelor of Sport \& Recreation at AUT University, Auckland, New Zealand. 
Martin, Fleming, Ferkins, Wiersma and Coll (2010) Facilitating and integrating learning with sport studies cooperative education: Exploring the pedagogies employed by students, academics and workplace supervisors

of learning also consisted of reflection on personal growth, rather than critical reflection on theory or organisational practice.

Keywords: work integrated learning; critical reflection

\section{Introduction}

Within the university setting (also referred to as higher or tertiary education), work integrated learning (WIL) experiences aim to provide a bridge, for the student, between the academic present and their professional future. More specifically, WIL programmes seek to apply and merge theoretical knowledge gained in academic studies to workplace experiences, and to prepare students for a career by providing an opportunity to develop relevant professional skills (Coll \& Eames, 2004; Little \& Harvey, 2006). Also known as sandwich degrees in the United Kingdom (Ward \& Jefferies, 2004), or cooperative education and internships in North America, New Zealand and Australia (Sovilla \& Varty, 2004), the tripartite partnership between the student, the workplace organisation, and the university requires all parties in the relationship to assume distinct responsibilities, perform specific functions, and achieve benefits as a result of the involvement (Fleming \& Martin, 2007). These cooperative education opportunities provide a structured educational strategy integrating classroom studies with learning through productive work experience in a field related to a student's academic or career goals.

The term work integrated learning implies and emphasises the notion that it entails an integration of knowledge and skills gained in the tertiary education institution, and in the workplace. This paper explores the variety of explicit, implicit and expected pedagogies employed by students, academic and workplace supervisors to integrate on- and off-campus learning in cooperative education. The setting for this investigation was sport studies degree programmes, from two selected New Zealand universities.

It has been frequently reported that universities do not sufficiently emphasise the development of behavioural skills to prepare graduates for professional life (Coll \& Zegward, 2006). To overcome this issue, WIL programmes seek to provide graduates with a comprehensive skill set desired by potential employers, in particular the development of behavioural competencies such as self confidence, communication, customer relationship management, initiative, and relationship building (Archer \& Davidson, 2008; Dressler \& Keeling, 2004; Fleming \& Ferkins, 2006; Martin \& Hughes, 2009).

A report on graduate recruitment in the leisure industry in Australia highlighted that a strong knowledge base alone does not guarantee a new graduate employment, and that the personal attributes and capabilities of the graduate are considered to have a greater influence on success in the workplace (Bell, Crebert, Patrick, Bates \& Cragnolini, 2003). Bell et al. (2003) asked to what degree the work placement, as part of a degree programme, contributed to the development of generic skills and abilities. Results of this investigation acknowledged that there was strong support for university work placements as an important contributor to graduate skills development for employment. Among graduates of the leisure management programme at Griffith University, $82 \%$ of respondents agreed that university work placements provided sufficient opportunity to develop generic skills and abilities (Bell et al., 2003).

For the purposes of the current project, WIL was considered in the context of full-time undergraduate students engaged in work integrated activities as part of their programme of study within New Zealand universities. WIL is now widespread within New Zealand universities (New Zealand Association for Cooperative Education [NZACE], 2009; Coll \& Eames, 2007), and represents a key strategy for the development of work-ready graduates exiting the higher education or tertiary sector. Eames (2003a) noted that whilst there is a rich literature on the success of WIL programmes, this research is almost entirely concerned with operational outcomes for students, such as gaining employment more easily and advancing more rapidly in their careers. However, there is a lack of research into what WIL students learn, how they learn, and from whom they learn (Bartkus \& Stull, 2004; Eames \& Bell, 
Martin, Fleming, Ferkins, Wiersma and Coll (2010) Facilitating and integrating learning with sport studies cooperative education: Exploring the pedagogies employed by students, academics and workplace supervisors

2005). This research therefore sought to investigate pedagogical approaches that facilitate and integrate student learning between the workplace and classroom setting. The investigation drew on salient WIL constructs and models of learning and reflection, as discussed below.

\section{WIL/cooperative education and learning}

There is acknowledgement that learning within the university setting, which involves dissemination of knowledge and theory, and learning within the workplace, is different but complementary (Coll \& Eames, 2004). Learning within the workplace is seen to occur through "the mediation of instruction, participation, and scaffolding through the use of language, instruments, stories and other tools that constitute the everyday practice of the workplace" (Eames \& Bell, 2005, p. 166). However, for this learning to occur in a measured fashion, placement practitioners must design programmes and placement structures that encourage learning as a situated, participatory and socially-mediated activity (Eames \& Bell, 2005). Boud and Falchikov (2006) argued that WIL should not be purely for the preparation of work-ready graduates but also enable students to develop skills as lifelong learners. Gray (2007) distinguished between personal reflection of the reflective practitioner (Schön, 1991) and critical reflection involving professional learning. However, this distinction may not be evident in the WIL process, as critical reflection on personal and professional learning and development are coupled together and promoted equally.

A key aspect of WIL/cooperative education is the notion that it entails the integration of knowledge and skills gained in the tertiary setting and in the workplace. It is the integration aspect of WIL that distinguishes it from workplace learning, in other words from simply what a student or employee learns whilst resident in the workplace (see Boud, 2000). Integration involves the student taking what he or she has learned in the workplace, and relating it to, or incorporating it into, the next phase of academic learning when they returns to the university after completing a work placement. Conversely, theories learned in the classroom are integrated into practice during the student's workplace experience (Van Gyn, Cutt, Loken \& Ricks, 1997; Parks, 2003). There is little reported research about how knowledge learned during the classroom experience is integrated into the workplace during WIL experiences, and even less known about the transfer of knowledge and experiences from the workplace back into the classroom (Wong \& Coll, 2001).

The work of Grollman and Tutschner (2006) and Stenstrom et al., (2006) emphasised the need for integration of on-campus and off-campus learning within the vocational education and training setting. However, these works work represent descriptions of current practice rather than empirical based research designed to understand further the integrative nature of classroom and WIL. In other studies on cooperative education, several items or topics have been identified as likely to be integrated as a result of WIL/cooperative education. These are, as might be expected, mostly generic skills such as the application of theory (Furco, 1997), increased discipline thinking (Cates \& Langford, 1999; Rankin, 1984), problem-solving (Burchell, Hodges \& Rainsbury, 2000) and behavioural skills (Carrell \& Rowe, 1994), time management (Parks, 2003), and teamwork and cooperation (Burchell et al., 2000; Weisz, 2000).

Although research that focuses on the integration of learning within WIL/cooperative education is sparse, Apostolides and Looye (1997) suggested a combination of course work (i.e., classroom or on-campus learning) and cooperative experiences (i.e., workplace learning) where assessment of student learning might well need to incorporate assessment of integration. Dewey (1938) provided the theoretical underpinnings of this structure, which involved reflection, guided by educators, that links different contextual environments and concepts, and the present study investigated student learning. 


\section{WIL/cooperative education and reflection}

The Kolb (1984) model of experiential learning highlights the importance of reflection, which is central to the cooperative education learning cycle (Eames \& Cates, 2004). Reflection-onaction requires reflection after the event. Reflection-in-action means to think about what one is doing while one is doing it. This process is commonly associated with experienced practitioners (Schön, 1991), but does not often come naturally (Gray, 2007). Reflectionbefore-action is preceded by reflection-on-action and reflection-in-action. Gibbs (1988) proposed a six stage model to develop student skills in reflection-before-action.

1. Description of the event.

2. Feelings and thoughts, the notion of self awareness.

3. Evaluation in which the student tries to evaluate or make a judgement about what has happened.

4. Analysis in which the student tries to break the event down into its component parts so they can be explored separately.

5. Conclusion and synthesis, which differs from the evaluation stage, in that now the student has explored the issue from different angles and has a substantial amount of information to base judgement on.

6. Formulation of an action plan, where the student should think forward into encountering the event (or similar event) again, and to plan what they would do would they act differently or would they likely do the same?

Gibb's model incorporates the core skills of reflection and is similar to Moon's (2000) sequence of reflective stages that participants move through - noticing, making sense, making meaning, working with meaning and, in some cases, transformative learning. Arguably Gibb's model is focused more on reflection-on-action, but it can also be used to focus on reflection in and before action. It is consistent with Boud's notion of lifelong learning and its focus on forward thinking (Boud \& Falchikov, 2006; Boud, Keogh \& Walker, 1985). While it can be argued that students may have difficulty undertaking purposeful reflection in the workplace setting, modern technologies allow academic supervisors to foster such reflection via, for example, on-line reflective journals/discussion.

Coll, Lay, and Zegwaard (2002) suggested that student learning can be mentored by a process of "enactive mastery" (i.e., scaffolding learning in the workplace increases confidence as tasks are mastered (Vygotsky, 1978; 1986), verbal persuasion (i.e., positive verbal encouragement from their mentors), and personal evaluation of their own capabilities, leading to increased self-efficacy. How, then, might the different pedagogies employed within WIL programmes in sport studies impact on the integration of learning between the classroom and workplace setting?

\section{Research design}

This study employed an interpretive framework involving a case study methodology (Bassey, 1999; Merriam, 1998), which permitted the researchers to gain an in-depth understanding of the issues of interest and to explore meaning from a number of angles (Merriam, 1998). Case studies are a very common approach used in WIL research because of the highly contextualised nature of such programmes (Coll \& Chapman, 2000; Linn, Howard \& Miller, 2004). The use of qualitative data analysis in this case study aimed to communicate understanding from the different stakeholders involved in the focus group interviews, for example, students, academic and workplace supervisors (Stake, 2008).

The study involved researchers and practitioners working together in the investigation of WIL programmes in two universities. The researchers in this study were all WIL practitioners, who currently act, or in the recent past had acted, as work placement coordinators/academic supervisors. Such coordinators work to secure or facilitate work placements for WIL students, provide support in the delivery of WIL, and offer career advice. In New Zealand, as worldwide, such practice is not well informed by research (Bartkus \& Stull, 2004), although this situation has improved in recent times. 
Martin, Fleming, Ferkins, Wiersma and Coll (2010) Facilitating and integrating learning with sport studies cooperative education: Exploring the pedagogies employed by students, academics and workplace supervisors

\section{Cohorts}

There were two cohorts for this study. The first consisted of participants involved with the three year Bachelor of Sport and Recreation (BSR) degree programme, from majors in Outdoor Education, Physical Activity and Nutrition, and Exercise Science, at AUT University, Auckland, New Zealand. The WIL placement experience within this cohort (as described in course/paper outlines) consisted of 350 hours working within one organisation throughout the final academic year. This placement was generally undertaken over two days per week. The second cohort was drawn from a three year Bachelor of Business Studies (Sport Business Management) or Bachelor of Sport and Exercise (Management and Coaching) degree from Massey University, Palmerston North, New Zealand. Their double semester placement consisted of approximately 180 hours (as described in course/paper outlines). As part of the WIL experience of both cohorts, the students had to complete a project that would be beneficial for the organisation (Fleming \& Martin, 2007).

\section{Data collection}

A semi-structured interview was an appropriate method to reveal respondents' opinions and beliefs on this research topic (Easterby-Smith, Thorpe, \& Lowe, 1991; Linn et al., 2004), and drew upon relevant literature, particularly the work of Eames (Eames, 2003a; Eames \& Bell, 2005). The questions focused on pedagogies used on campus, on placement, on both and associated learning. The analysis of relevant documentation (i.e. course/paper outlines, graduate profiles, etc.) provided data triangulation. Focus group interviews were conducted across three stakeholder groups as follows:

- $\quad$ students/recent graduates; regarding their teaching and learning experiences at both the university and in their work placements; focus groups consisted of three to four students per cohort

- $\quad$ practitioners comprising university staff supervising student WIL projects; focus groups comprised three staff per cohort, and were drawn from the sport management or sport and recreation programmes in the same universities as the students mentioned above; all staff were experienced placement coordinators (experience ranged from 3 - 12 years supervising student placements);

- employers comprising work place supervisors; regarding current pedagogical strategies used to facilitate student learning in the workplace; focus groups consisted of four to five employers per cohort

The employers interviewed were experienced professionals in the sport and recreation industry, with prior experience as supervisors of WIL students over a number of years. Each employer focus group had a WIL relationship with the same university as the students. Some of the participants had also taken on WIL students from other universities.

\section{Data analysis}

In each case, the focus group interviews and document analysis followed a proposal developed in advance of data collection. All the interviews were audio-taped and fully transcribed by an independent researcher, who had not conducted the interviews. Data analysis involved the development of a Concept Profile Inventory (CPI) based on methods described in the education literature (Erikson, 1979, 1980; Rollnick \& Rutherford, 1990). The $\mathrm{CPI}$ procedure consists of examination of interview transcripts for expressions and statements that could be construed as evidence for participants' views. These expressions were summarised and formed the unit of analysis. By examining the entire set of expressions in the transcripts, it was possible to gain a global perspective of the participants' views. These views were then organised into a series of categories which formed the conceptual inventory. Commonality of views among participants' conceptual inventories was deduced from examination of the individual inventories and used to address the research questions. The interpretations of the research findings given here are supported by extracts from the transcriptions. 
Martin, Fleming, Ferkins, Wiersma and Coll (2010) Facilitating and integrating learning with sport studies cooperative education: Exploring the pedagogies employed by students, academics and workplace supervisors

The credibility and dependability of the analysis was enhanced by triangulating the data across both cohorts, as well as the collection from different data sources. As noted above, this cross case analysis (Miles \& Huberman, 1994) involved three stakeholder groups plus relevant documentation and literature (Stake, 2008; Yin, 2003).

The research was interpretive in nature and philosophy. Key issues relating to quality in interpretive research are well documented in the literature (see Guba \& Lincoln, 1989, 1994; Merriam, 1998; Peshkin, 1993, for examples) and mostly comprise aspects such as potential for researcher bias, generalisability of findings, and reliability, many of which apply to research in cooperative education (Coll \& Chapman, 2000). Whilst it is recognised that the extent of generalisation from the research is limited, this is concordant with the nature of qualitative and case study research, which seeks to form a unique interpretation of events rather than produce generalisations. Transferability is the interpretive equivalent to generalisability and is enhanced here by the provision of a "thick" description (Merriam, 1998), which details the context, method and data analysis procedures. It is expected that the findings of this current project can be transferred to other WIL contexts.

The project followed the human research ethics regulations for each university and the ethical guidelines of the New Zealand Association for Research in Education, including the principles of informed consent, privacy and confidentiality. Ethical approval was gained from the university ethics committee relevant to each cohort.

\section{Results}

The reporting of the descriptive responses in the case study attempts to convey the holistic understanding and meaning of the phenomena under study (Merriam, 1998).

\section{Pedagogies used}

The main pedagogical approaches used for the three groups of stakeholders were:

- students - reflective journals/ assignments, lectures/ workshops, group discussion, academic and industry supervisor feedback

- academic supervisors - practical case studies, models, frameworks, problem solving, class discussion

- employers - employee focus, human resource management practices, undertaking a range of tasks

Students reported that they had experienced the traditional pedagogies of lectures and workshops on campus. Academic supervisors indicated that theoretical classes (lectures, tutorials, seminars) are made as practical as possible and aim to lead towards the capstone WIL project involving the placement organisations (Martin \& Leberman, 2005).

It's those kinds of practical elements that come into the courses that, for me, allow them to take those experiences into their [WIL experiences] and later on into the work force. And at least they have had some kind of experience with those things before they get out there.

Academics also reported that they often provided models or frameworks for students to reflect on during practical situations, such as working through and problem solving real scenarios, delivering a lecture on theoretical concepts, and then applying these to their WIL experiences.

You put them into less threatening situations and give them some context before they get into that environment. And then you can come back and reinforce that reflection of the things that did matter and it's easy to pick up on the little bits and pieces that you may have not guided them in. 
Martin, Fleming, Ferkins, Wiersma and Coll (2010) Facilitating and integrating learning with sport studies cooperative education: Exploring the pedagogies employed by students, academics and workplace supervisors

Inviting staff and graduates from the sport industry to talk about their experiences in classes is another way academics sought to link theory to practice. One academic stated that students "may not necessarily get a chance to do the hands on stuff but they listen to somebody else that has, who then shares their thoughts on how good the theory is, or isn't".

Interestingly, most of the employers were not familiar with what pedagogies were used on campus, but expected learning on campus to include theory, specifically basic event management theory; knowledge of organisation structure and function; and planning and project management processes. One employer noted that pedagogies might include, "some sort of theory on the principles of planning and project management". Another stated: "some sort of background knowledge of organisation structure and how an organisation is structured and functions. Then when they get on to the practicum they can see that part of it".

Students identified that they learnt from supervisors and work employees, as well as from their peers who were doing WIL at the same time. The different pedagogies included in the WIL experience also catered for different types of learners: "I'm pretty kinaesthetic so I'm hands on - so [the WIL experience] was a major for me".

Group interaction was identified as an important learning strategy while out in industry: "being in that kind of environment [i.e., placement] you have the opportunity to use all the people around you to learn well so you have got someone to bounce ideas off or get a piggy-back from". Another student noted, "the classes seem to be more group-oriented with people having group support ... It was kind of a good opportunity for classmates to discuss what was going on in each other's [projects] and provide support for problems or issues".

On-campus learning exposed the sport studies students to a range of different topics and themes, depending on the nature of the major the students were undertaking. Students typically commented that they felt they had a base level of knowledge and skills that they had gained while at university, but that they also needed to learn how to reflect critically prior to going on placement. One student stated: "it wasn't necessarily the sport specific subjects that you could take into your [WIL experience] but it was more the theories that you learnt from the core papers - the underlying foundation kinda stuff". Another student noted:

I learnt in class a way of thinking, we were introduced to different ideas and theories and it gave us the opportunity to have a broad way of looking at things. In sociology we learnt some theories and that helped me to shape the way that I then go into the outdoors and look at different industries and look at different people and situations.

The students felt that there needed to be some understanding by the industry as to what knowledge they had prior to entering the WIL experience. Expectations as to what the students were able do needed to be clear but there should also be flexibility so students did not miss an opportunity to do something that is a great learning experience.

You have done all this learning you must be able to do all these things, but I had done all this learning and co-op [i.e., WIL] was my opportunity to start applying it but not my opportunity to be put right out on the edge and to say oh here's a group, you take it, off you go.

Employer approaches to student learning on placement consisted primarily of exposing students to a wide range of tasks and activities and, in some cases, letting a student experience a full planning process from start to finish. One employer explained that they sought to, "empower them as an employee and give them the opportunity to take charge of something, make mistakes, and learn from that". Another recounted: "I made sure ... I had [a student] go through the whole action plan of the event ... so, they were involved from the beginning of a process for the event". 
Martin, Fleming, Ferkins, Wiersma and Coll (2010) Facilitating and integrating learning with sport studies cooperative education: Exploring the pedagogies employed by students, academics and workplace supervisors

Students were often included in weekly meetings and exposed to some form of induction and/or training as would occur with any new employee. In some cases a detailed job description and formal performance evaluations were provided for their students, as for full time staff.

\section{Assessment strategies used}

Facilitated assessment strategies outlined in the course descriptions for the two WIL programmes included:

- project proposals and learning contracts

- industry evaluation forms

- logs and reflective journals

- oral presentations, written critical reflections

- final written reports (Fleming \& Martin, 2007)

As stated by a student, "with all the written work it teaches you to critically evaluate your own performance". Another student noted: "your professional learning outcomes and personal learning outcomes form the basis or structure of what you'd be doing, like a foundation". However, the students did not always understand the importance of the reflective journal and for one participant the way he had learned at university was not seen as effective as what was learned in the workplace:

I got in the habit, when it came to university, almost to rote learn information and when it came to the workplace it didn't really work too well. Actually I had to think, be innovative of what needed to happen.

Initial one-to-one meetings with supervisors and students enable a focus on individual needs and emphasize the importance of matching students' expectations to projects and supervisors (Martin \& Leberman, 2005). The focus is on developing, in conjunction with the work place supervisor, a project and range of organisational experiences that provide opportunities for the student to build relationships. As noted by a student, "It's based on your relationship. If you can build that relationship before you actually go to the work force, then you are in a hell of a lot better position".

Academics indicated that the workplace supervisors (i.e., employers) provided both formal and informal verbal feedback and written evaluations of the students learning. "Supervisor evaluations give us sometimes a pretty good indication of where [the students] are at in terms of where their skills are lacking, etc... or whether they actually really moved ahead, or progressed on".

\section{Student learning}

Key themes related to student learning were:

- self-confidence and communications skills

- initiative and personal planning, and organisational skills

- industry and business knowledge and customer service management

- professional networks and professional ethics

Within these cooperative education programmes there is a focus on developing graduate competencies, as part of a whole course of study (Fleming, Zinn, \& Ferkins, 2008; Martin \& Hughes, 2009; Martin \& Leberman, 2005), involving both industry specific and behavioural skills. This focus was confirmed by document analysis of course and programme outlines. The development of industry skills is focused on specific content areas (e.g., event management), whereas behavioural skills are focused on developing aspects such as communication (e.g., verbal and written) or attitudinal skills (e.g., initiative, willingness, confidence). An academic supervisor stated: 
It's like part of a coherent course of study and I think particularly, the introduction of the sport management planning paper [ ${ }^{\text {nd }}$ year] has assisted with that because now you're not trying to cram everything into one paper in the third year, so it actually preps them and gives them some understanding of what they actually need to do ... how to manage a project, so they're going to get skills around financial planning, budgeting, running a project, risk management, writing press releases.

Academic practitioners also indicated that WIL provides an opportunity to develop life skills of communication, confidence, and self-esteem. "The focus of it for me is to build their selfesteem ... to enable them to match their graduate profile ... which is all of those kinds of skills, like confidence". Another stated: "in the sports industry particularly, you are always dealing with people and you need to be able to talk to people and convey ideas".

As might be expected, the students thought that professionalism was best learned on placement as "the whole work ethic and the understanding of what it is about [happens] when you go to work". This situation was particularly important for students that had come to university straight from school: "If you hadn't been out in the real world before it's that whole exposure thing". The off-campus WIL experiences were considered the best place to improve behavioural skills that are also considered transferable skills. This finding is consistent with previous research with cooperative education sport studies students (Fleming \& Eames, 2005; Fleming \& Ferkins, 2006; Martin \& Leberman, 2005). People skills and confidence were identified specifically: "You get confidence from what you were doing and what you were achieving that you kind of take away with you and put it into other aspects of your life".

When returning to university, it was identified that the behavioural skills were able to be transferred back into the classroom learning environment. One student noted, "I took back fluency of communication, written communication skills I can use in my future assignments, time management and organisation". Another stated, "You have more respect for organisations as now you know what they do. The real life examples help. You can then apply what you are learning back on campus to the experiences you have had".

Employers also reported behavioural skills such as self-confidence and communications skills were learned while on placement, as well as multi-tasking, prioritising and time management. "One of the things that struck me is that as opposed to learning the actual nuts and bolts and operational stuff was the development as people ... so self-confidence, self-belief ... communication skills."

The employers also reported that key learning outcomes related to a better understanding of what really goes on in a job (i.e., how an organisation functions and the culture of the organisation. In essence, the on-placement experience provided a reality check:

That one thing doesn't happen after the other, five things happen at once ... I don't think they realised the amount of paper work that happens, they thought they would be out there on the front line, coaching and taking teams as opposed to doing all the stuff that happens before that ... there are very few jobs in life that don't have a tedious boring, pain in the ass element to it ... they didn't really have any understanding of what goes on behind the scenes - I think they definitely have an appreciation of that now.

Another employer expressed that, "they must pick up the culture of the organisation in terms of their attitude with punctuality and work ethic, all those sorts of issues that you would pick up in any sort of workplace and they all differ from workplace to workplace".

Other comments about on-placement learning related to customer service skills, and the importance of attention to detail. As one employer explained, the students learned "how do we treat our ... members ... how do we treat our clients, group of school kids who were doing all sorts of activities, or whatever it might happen to be". Another employer 
Martin, Fleming, Ferkins, Wiersma and Coll (2010) Facilitating and integrating learning with sport studies cooperative education: Exploring the pedagogies employed by students, academics and workplace supervisors

emphasised that, "you have to pay a lot of attention to detail, and that's something that's sort of missed out when you only focus on theory".

When asked how they knew that the students have learned from their placements, the groups had difficulty responding. They referred to intuitive knowledge such as knowing in the end which ones they would employ and which ones they would not, but acknowledged that often came down to the personality and initiative of the individual rather than something they specifically learned while on placement. They also reported that the student's ability to undertake a task successfully at the end of a placement was an indication of their learning: "Can they when left to their own or asked to complete a task that you've shown them or have learnt through exposure, can they get in there and do the job that you asked them to do?"

\section{Integrating learning across dual settings}

It was suggested by the students that communication skills should first be learned at university through case studies, but then they need to follow up this learning through the experiences while on placement: "where there are real situations, as there are no consequences in the classroom". Students commented that there was an expectation that there would be some degree of integration of on-campus learning on placement. It was acknowledged that the degree of integration of theory and practice was variable, and that it depended on the type of organisation and work activities the student was involved with, as well as the selection of papers/courses that the student had undertaken prior to entering the WIL experience. However, several student participants, when asked in the focus group, found it hard to separate the on-campus and on-placement learning, and felt that the WIL experiences "make a lot more sense", of what they had learned on campus and highlighted the value of the on-campus learning:

I did learn a lot of things before co-op [i.e., WIL] and during co-op. I was able to put them into practice and while I was putting them into practice new things came up. It's hard to separate them and say this was before and this was during and this was in the classroom or this was in co-op.

While you are sitting there in lectures and you are learning what you are learning but you don't know what it is you need to know. When you go into your organisation [WIL experience] then you learn what you need to learn. You don't realise the value of the information you are given until you get there.

However, one student could not see how integration of workplace learning with on-campus learning would always occur. "I could not see that practicum would help them pass their exams - I think they are completely different, I don't really see how they relate."

The students felt that supervisors, both academic and industry, were important in facilitating the integration of learning: "you, as the student, need to make sure that both industry and academic supervisors are there for you". However, the student needs to have the most significant role: "The student needs to be in the driver's seat like in quite a strong way".

The employers felt that students learn a variety of behavioural and industry specific skills from both on- and off-campus learning experiences, and that these two complemented and reinforced each other. "Life skills - you learn them at work and at uni ... it's one of those things it doesn't matter where you are learning them". Another employer explained that:

Perhaps there is a crossover between both in terms of embellishment of what's already been taken on board if you like, so each is supporting the other, in other words, the computer skills and the hard skills and the research skills and so forth that they have learnt here will be embellished and further practised and refined wherever applied ... it's a two way process. 
Martin, Fleming, Ferkins, Wiersma and Coll (2010) Facilitating and integrating learning with sport studies cooperative education: Exploring the pedagogies employed by students, academics and workplace supervisors

While theory may be learned on campus, a greater understanding occurs when putting that theory into practice during a work placement. The employers also felt that the placement gave students a better understanding of how organisations work and more realistic expectations. Behavioural skills were highlighted as important for those beginning a work placement. However, employers suggested that these skills are not necessarily taught on campus or on placement, but result from the individual's personality and a lifelong process of learning. Overall, all of the employers felt that the WIL experience gave students an advantage over others for future job prospects based on the wide range of experiences and networking opportunities provided. "The experience they've gained, the people they've worked with, the knowledge they've gained, I mean they have to recognise that as a launching platform ahead of others that haven't done that sort of thing."

Overall, the sport studies students felt they learned content and basic skills on campus and subsequently developed their behavioural skills and a sense of professionalism on placement. Reflective journals and assignments helped develop the capacity for metacognition. Students felt integration of on- and off-campus learning could be better facilitated by their academic supervisors, but should also be more student-driven.

Academic supervisors felt there was a focus on the development of graduate competencies and, while they saw integration as important, did not feel students were particularly capable at this. They saw the reflective journals as a key learning tool in terms of integration but felt that, although the on-campus learning activities were very practically-oriented, the students often found it difficult to reflect critically.

Employers saw students coming to them with a range of skills and abilities but with basic content knowledge, and saw their own role as exposing students to a wide range of tasks and activities. They tried to facilitate learning by treating students much the same as other new employees, and felt they learned behavioural skills such as self-confidence and communications skills, as well as multi-tasking, prioritising and time management, along with an understanding of workplace culture.

\section{Discussion}

This discussion is structured around the two salient constructs highlighted in the conceptual framework, reflection and learning within WIL/cooperative education. In particular, it considers how reflection and learning is integrated between industry and classroom settings.

\section{Pedagogies promoting integrative reflection}

In the current study academics felt that discussing and reflecting on the WIL experiences back on campus was particularly valuable with this cycle of reflection-on-action (Kolb, 1984; Schön, 1991) being able to be repeated.

Often they will go out and do their thing when they're out on placement and they come back into the class and we discuss what they experience and we reflect on it. So it's about, giving them the theory, letting them go out there and have a go at it. Then when they come back they discuss it and that's where the most learning happens. 'Cos they don't have time to reflect when they're out in the work environment often, so on campus provides them with this opportunity.

This reflective process, encouraged by supervisors, enables interaction of the different contextual environments and concepts, as advocated by Dewey (1938). Assignments are focused on developing skills promoting Bloom's Taxonomy (1956) when undertaking reflection. However, higher grades are often perceived as being achieved for the evaluation end of the spectrum (Gibbs, 1988), as opposed to a range of reflection stages - noticing, making sense, making meaning, working with meaning and, in some cases, transformative learning (Moon, 2000). In the current study, academics indicated that the reflective journal, in particular, was a significant way to facilitate learning and was "an integral part of our 
Martin, Fleming, Ferkins, Wiersma and Coll (2010) Facilitating and integrating learning with sport studies cooperative education: Exploring the pedagogies employed by students, academics and workplace supervisors

assessment" undertaken throughout the learning process, although often "where they still struggle the most". The initial learning contract was also seen as important in identifying the outcomes that shaped the overall framework for reflection, and how the two settings might work to integrate learning.

\section{Integration of student learning}

Socio-cultural aspects have been identified in previous research as important in student learning in the workplace (see, Eames, 2003a; Fleming \& Eames, 2005, for example). WIL experiences in sport studies often involve students learning by working alongside others and in teams. Through the experience of this type of learning during WIL the students identified that this was also a good way to learn in the classroom setting: "social interaction inside the classroom is kind of an easy way to learn as you kinda draw on the ideas of others".

The pedagogies employed off-campus tended to be more informal in nature than the oncampus pedagogies, and consisted of inductions and one-to-one mentoring. There is no consistent mechanism by which off-campus supervisors or mentors seek to employ or develop pedagogies to foster learning. Learning is thus by means of legitimate peripheral participation (Rogoff, 1995), with student off-campus learning occurring alongside professionals in their area via an apprenticeship model of learning (Lave \& Wenger, 1991; Rogoff, 1995). Skills gained in off-campus learning are mostly behavioural "people skills" such as communication, time management, an understanding of workplace culture, treating others with respect, a good work ethic, and developing a sense of professionalism, culminating in an appreciation of what it means to be a professional in their specialty area (Eames, 2003a, 2003b; Eames \& Bell, 2005; Fleming, et al., 2008).

There seems to be clear recognition of distributed cognition, in that all stakeholders consider that students learn in a variety of ways, from many sources, with knowledge resident in lots of places across an organisation (Perkins, 1997). Wertsch (1991) also talked of situated cognition where the learning is specific to the setting (see also Lave \& Wenger, 1991). For example, what the students report as learning, supported by the views expressed by employers and academics, depends on the setting. That is, they report learning factual material such as content in the classroom, and behavioural skills in the workplace. However, consistent with Eames's (2003a, 2003b) work, the knowledge that students learn in, for example, a sport organisation, is specific to that industry and that firm - "the way we do things around here, the acronyms we use and so on".

\section{Conclusions}

This study investigated the pedagogies that facilitate and integrate student learning between the workplace and classroom. It found that there was minimal evidence of direct explicit attempts to integrate on- and off-campus learning, although all parties expected this would occur and agreed it should occur. However, integration was found to be implicitly or indirectly fostered by a variety of means. The principal means for fostering integration of on- and offcampus learning was by reflection via, for example, reflective journals and assignments/reports post-placement. This integration mostly consisted of reflection-on-action (Schön, 1991), after the learning activities, and was primarily orientated toward reflection on personal growth.

The distinction proposed by Gray (2007) between personal reflection and reflection on theory, and organisational practice, is therefore a key concept that could be used to develop WIL programmes in the future. Similarly, Gibb's (1988) model is a useful approach, which may assist in the staged deconstruction of incidents, using theoretical concepts. The more contemporary ideas posed by Moon (2000) in identifying the sequence of reflective stages could also be applied to WIL programmes to achieve greater integration of learning, not only between classroom and workplace settings but also between personal and professional learning. 
Martin, Fleming, Ferkins, Wiersma and Coll (2010) Facilitating and integrating learning with sport studies cooperative education: Exploring the pedagogies employed by students, academics and workplace supervisors

The study also confirmed that assessment of WIL programmes, as advocated by Eames and Bell (2005), should reflect the complexity of the dual and complementary nature of the learning environments. WIL assessments should also create opportunities for learners to understand and pursue the distinction between personal growth and critical reflection on organisational practice.

\section{Practical implications}

The students, academic supervisors, and employers have collective responsibility for the integration of learning through WIL. However, the design of WIL programmes rests largely with practitioners within university settings. The practical outcomes of this research therefore primarily target the academics that co-ordinate and supervise WIL programmes. WIL programmes should formally state that they require integration of knowledge, as an explicit learning objective. In the early stage of WIL, students need to be equipped with the basic content knowledge necessary for their discipline of study, exposure to the profession (e.g., visits to the workplace, employer presentations on-campus, real life case studies, viewing workplace documents), and critical thinking skills. Development of students as reflective practitioners then requires progression in complexity and sophistication. Students need to see the relevance of on-campus learning and how it might apply to the workplace setting before they go on placement. Such activities are often already part of many WIL programmes, but should be directly linked to the notion of integration and built into assessment tasks.

\section{Acknowledgement}

This project was funded by a New Zealand Ministry of Education Teaching and Learning Research Initiative Grant, which sought to develop the research base of education in work-

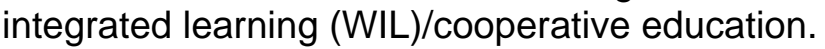

\section{References}

Apostolides, V., \& Looye, J. W. (1997). Student assessment of the co-op experience and optimum integration of classroom learning with professional practice. Journal of Cooperative Education and Internships, 32(3), 16-30.

Archer, W., \& Davidson, J. (2008). Graduate employability: What do employers think and want? London: The Council for Industry and Higher Education (ClHE),

Bartkus, K. R., \& Stull, W. A. (2004). Research in cooperative education. In R. K. Coll \& C. Eames (Eds.), International handbook for cooperative education: An international perspective of the theory, research and practice of work-integrated learning (pp. 67-78). Boston, MA: World Association for Cooperative Education.

Bassey, M. (1999). Case study research in educational settings. Buckingham, England: Open University Press.

Bell, B., Crebert, G., Patrick, C. J., Bates, M. \& Cragnolini, V. (2003). Educating Australian leisure graduates: Contexts for developing generic skills. Annals of Leisure Research, 6(1), 1-19

Bloom, B. S. (Ed.). (1956). Taxonomy of educational objectives: The classification of educational goals. New York: Longmans Green.

Boud, D. (2000). Sustainable assessment: Rethinking assessment for the learning society. Studies in Continuing Education, 22, 151-167. doi:10.1080/713695728

Boud, D., \& Falchikov, N. (2006). Aligning assessment with long-term learning. Assessment \& Evaluation in Higher Education, 31, 399-413. doi:10.1080/02602930600679050

Boud, D., Keogh, R., \& Walker, D. (Eds.) (1985). Reflection: Turning experience into learning. London: Kogan Page.

Burchell, N., Hodges, D., \& Rainsbury, L. (2000). What competencies do business graduates require? Perspectives of New Zealand stakeholders. Journal of Cooperative Education and Internships, 35(2-3), 11-20.

Carrell, S. E., \& Rowe, P. M. (1994). Effects of cooperative education on student adaptation to university. Journal of Cooperative Education and Internships, 29(1), 33-40.

Cates, C. L., \& Langford, D.R. (1999). Documenting communication and thinking skills through co-op student reports. Journal of Cooperative Education and Internships, 34(3), 7-17.

Coll, R. K., \& Chapman, R. (2000). Qualitative or quantitative? Choices of methodology for cooperative education researchers. Journal of Cooperative Education and Internships, 35(1), 2534. 
Martin, Fleming, Ferkins, Wiersma and Coll (2010) Facilitating and integrating learning with sport studies cooperative education: Exploring the pedagogies employed by students, academics and workplace supervisors

Coll, R. K., \& Eames, C. (2007). Learning science and technology through cooperative education. Asia-Pacific Journal of Cooperative Education, 8, 131-147.

Coll, R. K., \& Eames, C. (2004). International handbook for cooperative education: An international perspective of the theory, research and practice of work-integrated learning. Boston, MA: World Association for Cooperative Education.

Coll, R. K., Lay, M. C., \& Zegwaard, K. E. (2002). Enhancing access to experiential learning in a science and technology degree program. Journal of Vocational Education and Training, 54, 197217. doi:10.1080/13636820200200195

Coll, R. K., \& Zegwaard, K. E. (2006). Perceptions of desirable graduate competencies for science and technology new graduates. Research in Science \& Technological Education, 24, 29-58. doi:10.1080/02635140500485340

Dewey, J. (1938). Experience and education. New York: Collier Books

Dressler, S., \& Keeling, A. E. (2004). Benefits of cooperative education for students. In R. K. Coll \& C. Eames (Eds.), International handbook for cooperative education: An international perspective of the theory, research and practice of work-integrated learning (pp. 217-236). Boston, MA: World Association for Cooperative Education.

Eames, C. (2003a). Learning through cooperative education. Unpublished PhD thesis, University of Waikato, Hamilton, New Zealand.

Eames, C. (2003b). Learning to work: Becoming a research scientist through work experience placements. Asia-Pacific Journal of Cooperative Education, 4(2), 7-15.

Eames C., \& Bell, B. (2005). Using sociocultural views of learning to investigate the enculturation of students into the scientific community through work placements. Canadian Journal of Science, Mathematics and Technology Education, 5, 153-169. doi:10.1080/14926150509556649

Eames, C., \& Cates, C. (2004). Theories of learning in cooperative education. In R. K. Coll \& C. Eames (Eds.), International handbook for cooperative education: An international perspective of the theory, research and practice of work-integrated learning (pp. 37-48). Boston, MA: World Association for Cooperative Education

Easterby-Smith, M., Thorpe, R., \& Lowe, A. (1991). Management research: An introduction. London: Sage.

Erickson, G.L. (1979). Children's conceptions of heat and temperature. Science Education, 63, 221230. doi:10.1002/sce.3730630210

Erickson, G.L. (1980). Children's' viewpoints of heat: A second look. Science Education, 64, 323- 336. doi:10.1002/sce.3730640307

Fleming, J., \& Eames, C. (2005). Student learning in relation to the structure of the cooperative education experience. Asia-Pacific Journal of Cooperative Education, 6(2), 26-31.

Fleming, J., \& Ferkins, L. (2006). Enhancing student employability: A New Zealand case study of cooperative education in sport. In N. Becket \& P. Kemp (Eds.), Enhancing graduate employability in business and management, leisure, sport and tourism (pp. 98-105). Newbury, England: Threshold Press.

Fleming, J., \& Martin, A. J. (2007). Facilitating reflective learning journeys in sport cooperative education. Journal of Hospitality, Sport, Tourism, Leisure and Education, 6(2), 115-121. doi:10.3794/johlste.62.171

Fleming J., Zinn, C., \& Ferkins, L. (2008). Bridging the gap: Competencies students should focus on during their cooperative experience to enhance employability. In D. Jorgensen (Ed.), Proceedings of the WACE/ACEN Asia Pacific Conference (pp. 155-163). Sydney, Australia: WACE.

Furco, A. (1997). Service-learning and school-to-work: Making the connections. Journal of Cooperative Education and Internships, 32(1), 7-14.

Gibbs, G. (1988). Learning by doing: A guide to teaching and learning methods. Oxford, England: Further Education Unit.

Gray, D. E. (2007). Facilitating management learning: Developing critical reflection through reflective tools. Management Learning, 38, 495-517. doi:10.1177/1350507607083204

Grollman, P., \& Tutschner, R. (2006). Possible intended and unintended effects of European VET policies: The case of integrated work and learning. Bremen, Germany: University of Bremen.

Guba, E. G., \& Lincoln, Y. S. (1989). Fourth generation evaluation. Newbury Park, CA: Sage.

Guba, E. G., \& Lincoln, Y. S. (1994). Competing paradigms in qualitative research. In N. K. Denzin \& Y. S. Lincoln (Eds.), Handbook of qualitative research (pp.105-117). Thousand Oaks, CA: Sage.

Kolb, D.A. (1984). Experiential learning: Experience as the source of learning and development. Englewood Cliffs, NJ: Prentice Hall.

Lave, J., \& Wenger, E. (1991). Situated learning: Legitimate peripheral participation. Cambridge, England: Cambridge University Press.

Linn, P. L., Howard, A., \& Miller, E. (Eds.). (2004). Handbook for research in cooperative education and internships. Mahwah, NJ: Lawrence Eribaum

Little, B., \& Harvey, L. (2006). Learning through work placements and beyond. Sheffield/London: Sheffield Hallam University/Open University. 
Martin, Fleming, Ferkins, Wiersma and Coll (2010) Facilitating and integrating learning with sport studies cooperative education: Exploring the pedagogies employed by students, academics and workplace supervisors

Martin, A. J., \& Leberman, S. I. (2005). Keeping up with the play: Practicum, partnership and practice. Asia-Pacific Journal of Cooperative Education, 6(2), 17-25.

Martin, A. J., \& Hughes, H. (2009). How to make the most of work integrated learning. Palmerston North, New Zealand: Massey University.

Merriam, S. B. (1998). Qualitative research and case study applications in education. San Francisco, CA: Jossey-Bass.

Miles, M. B., \& Huberman, A. M. (1994). Qualitative data analysis. Thousand Oaks, CA: Sage.

New Zealand Association for Cooperative Education. (2009). Welcome to NZACE. Retrieved August 12, 2009, from http://www.nzace.ac.nzl

Moon, J. A. (2000). Reflection in learning and professional development: Theory and practice. London: Kogan Page.

Parks, D. K. (2003). An examination of cooperative education students' learning outcomes. Unpublished dissertation, Valdosta State University, Georgia.

Perkins, D. N. (1997). Person-plus: A distributed view of thinking and learning. In G. Salomon (Ed.), Distributed cognitions: Psychological and educational considerations (pp. 88-110). Cambridge, England: Cambridge University Press.

Peshkin, A. (1993). The goodness of qualitative research. Educational Researcher, 22(2), 23-29.

Rankin, J. A. (1984). Getting the most out of the industrial attachment phases of a cooperative engineering program. Journal of Cooperative Education and Internships, 21(1), 70-74.

Rogoff, B. (1995). Observing sociocultural activity on three planes: Participatory appropriation, guided participation and apprentice. In J. V. Wertsch, P. del Rio \& A. Alvarez (Eds.), Sociocultural studies of mind (pp. 139-164). Cambridge, England: Cambridge University Press.

Rollnick, M. S., \& Rutherford, M., (1990). African primary school teachers - what ideas do they hold on air and air pressure? International Journal of Science Education, 12, 101-113. doi:10.1080/0950069900120109

Schön, D.A. (1991). The reflective practitioner: How professionals think in action. Aldershot, England: Arena.

Sovilla, E. S., \& Varty, J. W. (2004). Cooperative education in the USA, past, present: Some lessons learned. In R. K. Coll \& C. Eames (Eds.), International handbook for cooperative education: An international perspective of the theory, research and practice of work-integrated learning (pp. 3-16). Boston, MA: World Association for Cooperative Education

Stake, R. (2008). Qualitative case studies. In N. K. Denzin \& Y. S. Lincoln (Eds.), Strategies of qualitative inquiry ( ${ }^{\text {rd }}$ ed., pp. 119-150). Los Angeles, CA: Sage.

Stenstrom, M.-L., Grollman, P., Tutschner, R., Tynjala, P., Nikkanen, P., Loogma, K., et al. (2006, September). Integration of work and learning: Policies, strategies and practices. Paper presented at the European Research Network in Vocational Education and Training Symposium, Geneva, Switzerland.

Van Gyn, G., Cutt, J., Loken, M., \& Ricks, F. (1997). Investigating the educational benefits of cooperative education: A longitudinal study. Journal of Cooperative Education and Internships, 32(1), 70-85.

Vygotsky, L. S. (1978). Mind in society: The development of higher psychological processes. Cambridge, MA: Harvard University Press.

Vygotsky, L. S. (1986). Thought and language. Cambridge, MA: MIT Press.

Ward, N., \& Jefferies, A. (2004). "The Analytical Club": A unique cooperative education link between industry and academia. Asia-Pacific Journal of Cooperative Education, 5(1), 15-18.

Weisz, M. (2000). Developing a measure of student attributes. Journal of Cooperative Education and Internships, 35(2-3), 33-40.

Wertsch, J. V. (1991). Voices of the mind: A sociocultural approach to mediated action. Cambridge, MA: Harvard University Press.

Wong, N. A., \& Coll, R. K. (2001). Student experience of international cooperative education: Reflections on personal and professional growth. Asia-Pacific Journal of Cooperative Education, 2(1), 11-18.

Yin, R. K. (2003). Case study research: Design and methods ( $3^{\text {rd }}$ ed.). Thousand Oaks, CA: Sage.

Submitted March 2009. Revised August 2009. Final Version October 2009. Accepted November 2009. 